\title{
Synthesis and biological activity of 3-azahetarylchroman-4-ones
}

\author{
Natalia V. Gorbulenko ${ }^{*}$, Tatyana V. Shokol, Vladimir P. Khilya \\ Department of Chemistry, Taras Shevchenko National University of Kyiv, \\ Lva Tolstogo Street, 12, Kyiv 01601, Ukraine \\ n_gorbulenko@ukr.net
}

Keywords: flavonoids, chromones, 3-hetarylchromones, nucleophilic substitution, cyclization, reduction/hydrogenation, 3-hetarylchroman-4-ones.

Articles reporting on the synthesis and biological activity of 3-hetarylchroman-4-ones are reviewed. The following preparative methods to 3-hetarylchroman-4-ones - nucleophilic substitution in 3bromochroman-4-ones, cyclization of 2-hydroxy- $\alpha$-hetarylacetophenones, reduction/hydrogenation of 3-azahetarylchromones, their benefits and disadvantages are described. The biological activity of 3-hetarylchromanones is also surveyed.

\section{Introduction}

The flavonoids are related to numerous cluster of natural polyphenolic compounds. They are widely spread in plants and are known as biologically active compounds. Chromones and coumarines with their derivatives belong to the class of flavonoids.<smiles>O=C1CCOc2ccccc2C1=O</smiles>

Figure 1. Benzopyran-4-ones’ representatives.
Natural chromones (benzopyran-4-ones) are represented in most cases by flavones (2arylbenzopyran-4-ones) and isoflavones (3arylbenzopyran-4-ones). The numeration of such system is also given in Figure 1.

The replacement of aryl radical in the isoflavone molecules on such pharmacophores as nitrogen heterocycles leads to the new structures, named "double drugs", which are potential bispharmacophoric medicine remedy 3-azahetarylchromones. The researches that have been reported on the 3-hetarylchromones are both extensive and varied [1-4]. The hydrogenated chromone derivatives are of indubitable interest, owing to a wide spectrum of biological activity (estrogenic, anti-cancer, 
antiinflammatory,

antioxidative,

hepatoprotective, antimicrobial, hypolipidemic etc.) [5]. Considerable less information has been reported on the hydrogenated analogues of 3-

\section{Results and discussion}

There are three basic approaches for 3hetarylchroman-4-ones' preparation: nucleophilic substitution in 3-bromochroman-4ones, cyclization of 2-hydroxy- $\alpha$ hetarylacetophenones, reduction/hydrogenation of 3-hetarylchromones.

\section{Nucleophilic substitution in 3-bromo- chroman-4-ones}

It is possible to synthesize 3hetarylchroman-4-ones by nucleophilic substitution in 3-bromochroman-4-ones, although this method is of no practical significance for reasons that are discussed below.

It is known that 3-bromochroman-4-ones readily eliminate hydrogen bromide in the presence of alkali to form chromones. It is interesting to note that treatment of 3bromochroman-4-one with diethylamine in aqueous solution at room temperature was reported to give the diethylaminovinyl ketone, which could be readily converted into chromone by the action of ethereal hydrogen chloride [6]. Colonge and Guyot [7] described the reaction of 3-bromochroman-4-one 1 with piperidine and suggested the isolated product to be 3piperidinochroman-4-one 2 (Scheme 1). Further reinvestigation [8] indicated that the isolated compound was not $\mathbf{2}$, but identical with $o-$ hydroxy- $\beta$-piperidinoacrylophenone $\mathbf{3}$, obtained according to Winter and Hamilton [9] after treatment of chromone with piperidine. It can be assumed that the first step of the above reaction consists in the formation of chromone with subsequent production of $\mathbf{3}$. However, as the formation of $\mathbf{2}$ could not be excluded, the treatment of $\mathbf{1}$ was performed with the calculated amount ( 2 moles) of piperidine in dry benzene. After removal of the main product 3 the expected piperidinochromanone 2 could be isolated as its hydrochloride in poor yield ( $8 \%)$.

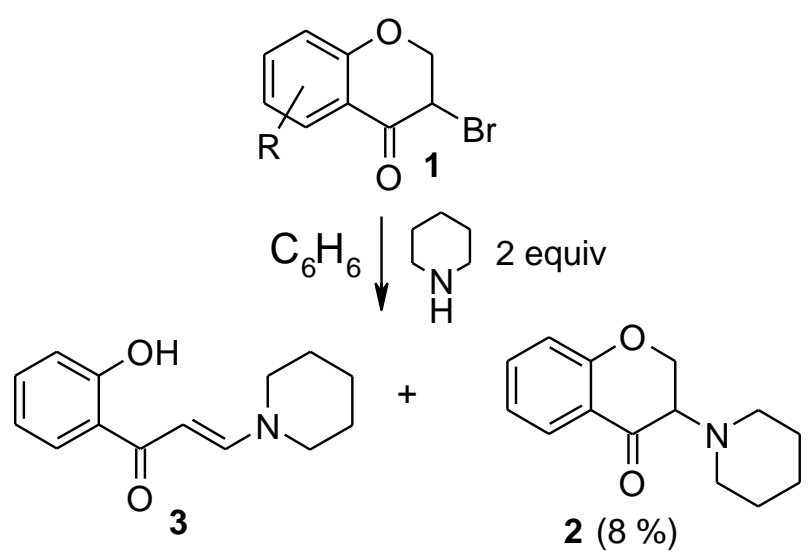

Scheme 1. The synthesis of 3-piperidinochroman-4-one.

The synthesis of 3-(1H-imidazol-1-yl)chroman4-ones 4 was first attempted by reaction of the corresponding 3-bromochroman-4-ones 1 with excess of imidazole 5 in DMF (Scheme 2). Varying degrees of dehydrohalogenation of 3bromochroman-4-ones took place, giving the 
corresponding chromones $\mathbf{6}$ in addition to the desired compounds of formula 4. The side reaction giving chromones $\mathbf{6}$ could not be eliminated by changing the solvent and temperature or by using imidazole derivatives such as its sodium or silver salt or trimethylsililimidazole [10].<smiles>[R]c1cccc2c1C(=O)C(Br)CO2</smiles><smiles>[R]c1ccc2c(c1)C(=O)C(n1ccnc1[18O])CO2</smiles>

Scheme 2. The synthesis of 3-(1H-imidazol-1-yl) chroman-4-ones.

The 3-(imidazol-1-yl)chroman-4-one series was obtained by modifying a substituent on the phenylene ring of the parent compounds ( $R$ group in Scheme 2) [11].

By reacting pyrazole with 3bromochroman-4-ones under similar conditions the unreacted materials were recovered [10].

The synthesis of 3-(1H-1,2,4triazol)chroman-4-one 7 was first attempted by reaction of the 3-bromochroman-4-one with an excess (3-5 moles) of 1,2,4-triazole by refluxing in DMF [12], a procedure similar to the one discribed by Strehlka et al. [13]. The latter reaction did not give desired 3-hetarylchroman4-one 7 and the starting material was recovered (98\%). When 1,2,4-triazole was reacted with 3 - bromochroman-4-one in the presence of $\mathrm{K}_{2} \mathrm{CO}_{3}$ in $\mathrm{MeCN}$, in a procedure similar to those reported by Lai et al. [14], dehydrohalogenation of $\mathbf{1}$ took place giving the chromone $\mathbf{6}$ as the major product and the compound 7 in $12 \%$ yield (Scheme 3).

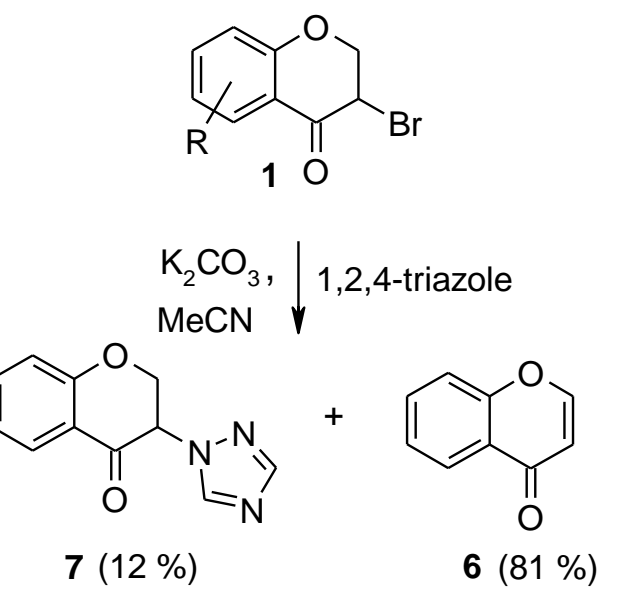

Scheme 3. The synthesis of 3-(1H-1,2,4-triazol-1yl)chroman-4-one.

However, the compound 7 could be synthesized in high yield as shown in Scheme 4.<smiles>[R]c1cccc2c1C(=O)C(Br)CO2</smiles><smiles>CC(C)CN(C)Cn1cnnc1</smiles><smiles></smiles>
$9(76 \%)$

$\mathrm{HNO}_{2}$<smiles>O=C1c2ccccc2OCC1n1cncn1</smiles>
$7(94 \%)$

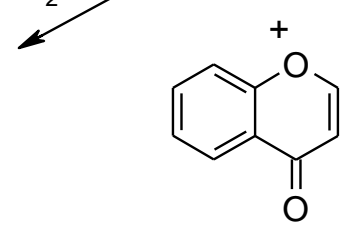

$6(8 \%)$

Scheme 4. The synthesis of 3-(1H-1,2,4-triazol-1yl)chroman-4-one.

Reaction of 3-bromochroman-4-one 1 with 1amino-1,3,4-triazole 8 in $\mathrm{MeCN}$ under reflux for one day thus gave the desired triazolium salt 9 in $76 \%$ yield. The chromone 6 was isolated in 
$8 \%$ yield as by-product. Diazotization of the salt 9 (with loss nitrous oxide) readily provided 7 in good yield (94\%).

2. The cyclization of 2-hydroxy- $\alpha$ hetarylacetophenones

A more convenient method for the preparation of 3-hetarylchroman-4-ones is based on the ring closure of 2-hydroxy- $\alpha$ hetarylacetophenones.

In the references $[15,16]$ it is shown that 3-(2-pyridinyl)chroman-4-one $\mathrm{N}$-oxides $\mathbf{1 0}$ and 11 were synthesized by cyclization of 1-(2hydroxyphenyl)-2-(2-pyridinyl)ethanone $\quad \mathrm{N}$ oxide 12 with 1 or 2 moles of formaldehyde subsequently (Scheme 5).<smiles></smiles>

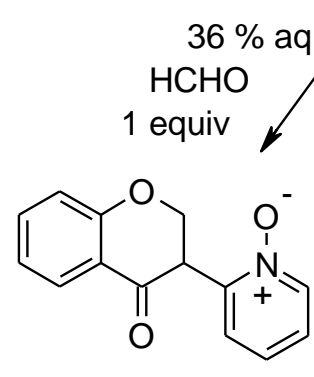

$10(28 \%)$ 12 pyrrolidine
$\mathrm{N}_{2}$, EtOH $\mathrm{HCHO}_{2}$ equiv $\triangle 5 \mathrm{~h}$<smiles></smiles>
$11(81 \%)$

Scheme 5. The synthesis of 3-(2-pyridinyl)chroman-4one $\mathrm{N}$-oxides.

In the search for new compounds of pharmacological interest a number of derivatives containing the imidazole and the chroman ring in the same molecule were prepared, as exemplified in Scheme 6 [10, 11].

2-(1H-Imidazol-1-yl)-2'-hydroxyacetophenones 13 were thus easily prepared by reaction of 2-bromo-2'-hydroxyacetophenones
14 with an excess of imidazoles in DMF (Method A). The azole residue plays an important role in enhancing nucleophilic reactivity on the methylene group of the generated acetophenones.<smiles>[R]c1ccc(O)c(C(=O)CBr)c1</smiles>

14

13<smiles>[R]c1ccc2c(c1)C(=O)C(n1ccnc1CCOC(=O)O)CO2</smiles>

15<smiles>[Y]C=O</smiles><smiles>[R]c1ccc2c(c1)C(=O)C(CO)(n1ccnc1[R])CO2</smiles>

$\mathrm{HCHO}$, r.t.

Method C

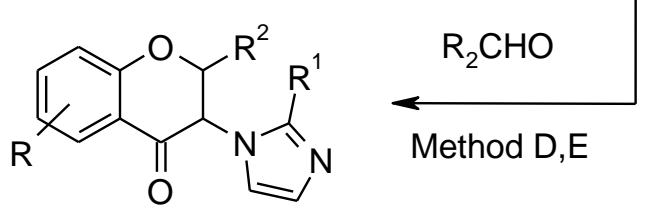

17

Scheme 6. The synthesis of 2-(un)substituted-3-(1Himidazol-1-yl)chroman-4-ones.

The ring closure of 2-(1H-imidazol-1yl)-2'-hydroxyacetophenones $\mathbf{1 3}$ to $3-(1 H-$ imidazol-1-yl)chroman-4-ones 15 was performed with paraformaldehyde in glacial acetic acid (Method B) with yields ranging from 45 to $70 \%$. Small amount of hydroxymethyl derivatives $\mathbf{1 6}$ were formed as by-products from a second electrophilic attack by formaldehyde. 
The compounds 16 could be obtained from 13 in high yields using an excess of paraformaldehyde in acetic acid or preferably using a $40 \%$ aqueous formaldehyde solution in the presence of sodium metabisulphite $\left(\mathrm{Na}_{2} \mathrm{~S}_{2} \mathrm{O}_{5}\right.$ Method C). Hydroxymethyl derivatives 16 could also be obtained from 15 itself with an excess of paraformaldehyde. Reaction of 2(1H-imidazol-1-yl)-2'-hydroxyacetophenones

13 with other aldehydes gave 2-substituted-3(1H-imidazol-1-yl)chroman-4-ones 17, predominantly in the trans configuration as shown by NMR spectral analysis. Glacial acetic acid (Method D) or an excess of the reacting aldehyde (Method E) were also used as solvents. The yields ranged from 55 to $95 \%$.

The ring closure depicted in Scheme 6 also works well for 1-pyrazolyl derivatives [10]. When pyrazole reacted with 2'-hydroxy-5'chloro-2-bromoacetophenone under reaction conditions similar to those of Method A, 2-(1Hpyrazol-1-yl)-2'-hydroxy-5' -chloroaceto-

phenone 18 was obtained. Reaction of the latter with acetaldehyde in acetic acid following Method D gave trans-6-chloro-3-(1H-pyrazol-1yl)-2-methylchroman-4-one 19 in $85 \%$ yield. The cognate compound 6-chloro-3-(1H-pyrazol1-yl)chroman-4-one 20 was obtained from the ketone $\mathbf{1 8}$ and paraformaldehyde in a very dilute solution of acetic acid (Method F). In contrast, under the usual conditions reported in Method B for the imidazole analogues, condensation of two molecules of 1-pyrazolyl derivative 18 with formaldehyde took place giving a compound to which the authors [10] assigned the structure of 3-(1H-pyrazol-1-yl)-3-(2-(2-hydroxy-5-

chlorobenzoyl)-2-(1H-pyrazol-1-yl)ethyl-6chlorochroman-4-one 21 (Scheme 7).

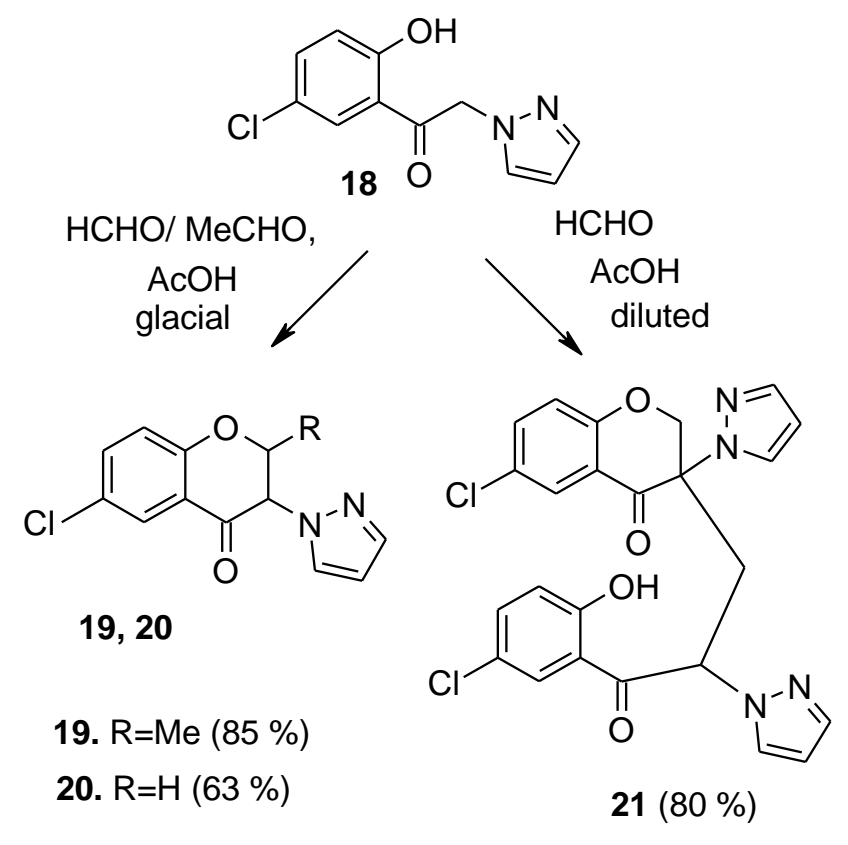

Scheme 7. The synthesis of 3-(1H-pyrazol-1-yl)chroman4-ones.

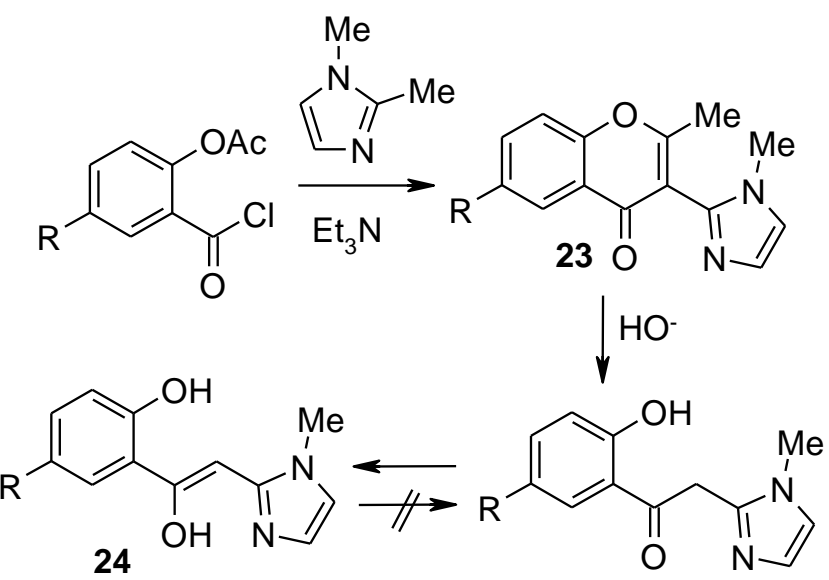<smiles>[M]C1Oc2ccc(OC)cc2C(=O)C1c1nccn1C</smiles>

$22(61 \%)$

Scheme 8. The synthesis of 2-methyl-3-(1-methyl-1Himidazol-2-yl)chroman-4-one. 
The synthesis of 2-methyl-3-(1-methyl- Treatment of $\mathbf{1 4}$ with an excess of 1,2,4-triazole $1 H$-imidazol-2-yl)chroman-4-one 22 has been in DMF gave a mixture of isomeric 2-hydroxydescribed [17] starting from 2-acetoxy-5- $\alpha$-triazolylacetophenones 25 and 26 in 1:2 ratio chlorobenzoyl chloride and 1,2- [12]. In addition, a quaternary triazolium salt, dimethylimidazole (Scheme 8). The the by-product 27, was isolated in 45-50\% intermediate chromone $\mathbf{2 3}$ here undergo alkaline yield. Direct alkylation of 1,2,4-triazole usually ring opening to the corresponding 1-(2-hydroxy- affords a mixture of mainly 1- and some 45-chlorophenyl)-2-(1-methyl-1H-imidazol-2substituted products (Scheme 9). The selectivity yl)ethenole 24. The latter in the presence of acetaldehyde in acetic acid at $90^{\circ} \mathrm{C}$ gives ring closure to the desired chroman-4-one 22 in pure trans form.

The isomeric 3-(1,2,4-triazolyl)chroman4-ones with an (un)substituted position 2 were synthesized through a similar procedure which was employed for diazolyl analogues of isoflavanones. The apparent straight-forward preparation of 2-hydroxy- $\alpha$ varies with the nature of the alkylating agent and the conditions employed, but ranges from 70:30 to $90: 10$ [19]. The problem of preparing $\alpha-(1 H-1,2,4-t r i a z o l-1-y l) a c e t o p h e n o n e s \quad 25$ in high yield was solved as indicated in Scheme 10.

Reaction of 4-amino-1,2,4-triazole 8 with 2bromo-2'-hydroxyacetophenones 14 gave pure samples of the triazolium salt $\mathbf{2 8}$, which on subsequent deamination with nitrous acid triazolylacetophenone was performed by yielded exclusively the 1-substituted product 25. displacement of 2-bromo-2'hydroxyacetophenones $\mathbf{1 4}$ by 1,2,4-triazole as reported by Baji et al. [18].<smiles>[R]c1ccc(C(=O)CBr)c(O)c1</smiles><smiles>[R]c1ccc(C(=O)Cn2cncn2)c(O)c1</smiles>
25 1<smiles>[R]c1ccc(C(=O)Cn2cnnc2)c(O)c1</smiles>

26<smiles>[R]c1ccc(C(=O)Cn2c[n+](CC(=O)c3ccc([3H])cc3O)cn2)c(O)c1</smiles>

2,3

Scheme 9. The synthesis of isomeric 2-hydroxy- $\alpha$-triazolylacetophenones. 


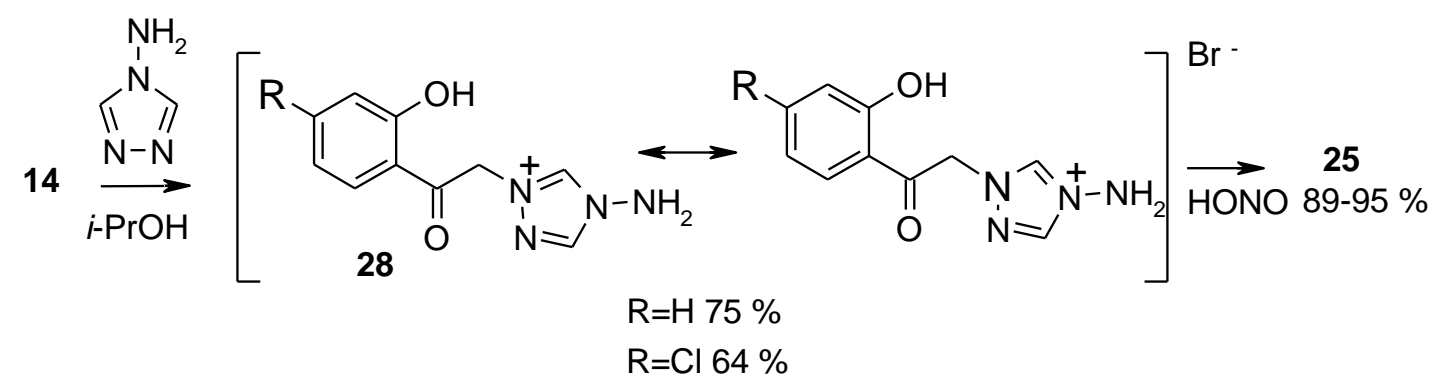

Scheme 10. The synthesis of 2-hydroxy- $\alpha$-(1H-1,2,4-triazol-1-yl)acetophenones.

Ring closure of the isomeric 2-hydroxy- $\alpha$ triazolylacetophenones 25 and 26 (Scheme 11) by paraformaldehyde in acetic acid at $90-100^{\circ} \mathrm{C}$ gave the corresponding 3-triazolylchromanones 29 and 30 in low to moderate yield [12, 20, 21].<smiles>[R]c1ccc(C(=O)Cn2cncn2)c(O)c1</smiles>

25<smiles>[R]c1ccc2c(c1)OCC(n1cncn1)C2=O</smiles>

29 $\mathrm{R}=\mathrm{Cl} 40 \%$<smiles>[R]c1ccc2c(c1)OC(C)[C@H](n1cncn1)C2=O</smiles>

32

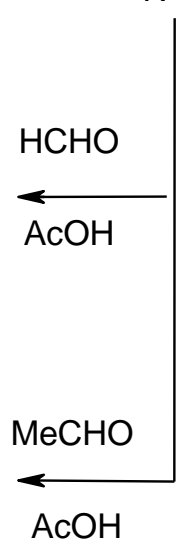

In the latter reaction in addition to 3-(4H-1,2,4triazol-4-yl)chroman-4-ones $\quad \mathbf{3 0}, \quad$ the corresponding hydroxymetyl derivatives $\mathbf{3 1}$ were obtained as by-products [12].<smiles>[R]c1ccc(C(=O)Cn2cnnc2)c(O)c1</smiles>

26<smiles>[R]c1ccc2c(c1)OCC(n1cnnc1)C2=O</smiles>

Scheme 11 The synthesis of isomeric 2-(un)substituted 3-(1,2,4-triazolyl)chroman-4-ones.

Analogous ring closure by acetaldehyde gave 2- group with respect to azole ring was assigned to methyl-3-(1,2,4-triazolyl)chroman-4-ones $\mathbf{3 2}$ a trans configuration, according to the quite and 33, where the configuration of the methyl 
large ${ }^{1} \mathrm{H}$ NMR coupling constant $(J=11,6-12,0$

Hz) [20, 22].

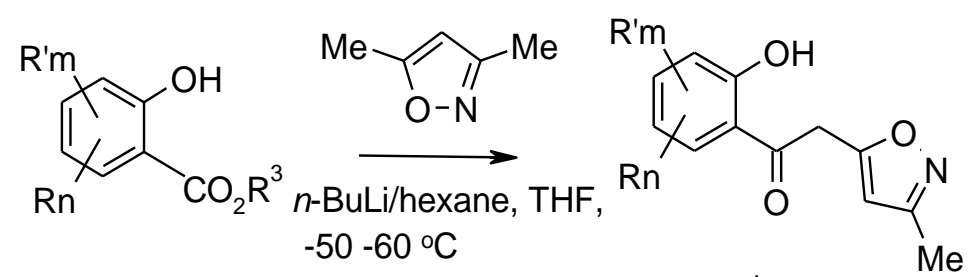

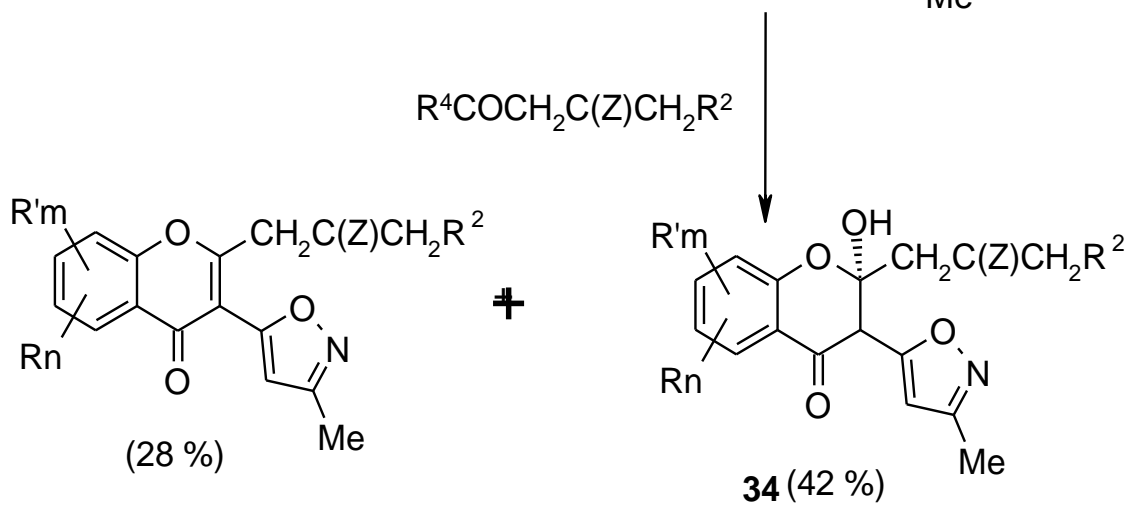

Scheme 12. The synthesis of 3-isoxazolylchroman-4-one derivatives.

The publications [23, 24] present information on the synthesis directed towards the fungal xanthone bikaverin. It is herein reported about 3-isoxazolylchroman-4-one derivatives 34 obtained, according to the method depicted in Scheme 12.

At first, the authors of the review have successfully used bisdimethylamino-methane in ethanol for the cyclization of the 2-hydroxy-4methoxy- $\alpha$-(quinolin-2-yl)acetophenone $\mathbf{3 5}$ into the corresponding 3-(quinolin-2-yl)chroman-4one 36 in $80 \%$ yield (Scheme 13). Work on this reaction is still in progress, especially aimed at extending the synthesis to other 3hetarylchroman-4-ones.<smiles>CCc1cc(C(=O)Cc2ccc3ccccc3n2)c(O)cc1OC</smiles><smiles>CCOc1cc2c(cc1OC)C(=O)C(c1ccc3ccccc3n1)CO2</smiles>

$36(80 \%)$

Scheme 13. The synthesis of 7-methoxy-6-ethyl-3(quinolin-2-yl)chroman-4-one.

\section{Hydrogenation of 3-hetarylchromones}

When a chromone is subjected to hydrogenation/reduction, several products can be isolated: chroman-4-ones, chroman-4-ols, chromenes and chromans. 
The reduction of chromones represents an important method for the synthesis of chroman-4-ones. Many methods of selective or unselective reduction of such compounds have been reported: with palladium on charcoal or other supports, or elemental palladium; with platinum, with Raney-nickel; with hydride complexes, with DIBAL-H or with homogeneous hydrogenation catalysts, etc. [5]. Some of them were used for the hydrogenation of 3-hetarylchromones.

\subsection{With palladium on carbon}

Hydrogenation on $\mathrm{Pd} / \mathrm{C}$ is the most widely used method for reduction of chromones. At first, selective hydrogenation of the isoflavones was accomplished by Szabo et al. $[25,26]$. The selectivity in the formation of dihydro-isoflavones was found dependent on the supplier of $\mathrm{Pd} / \mathrm{C}$ and $\mathrm{pH}-d e p e n d e n t$.

A starting point for hydrogenation of an unknown chromone can be a "titration with hydrogen" over $\mathrm{Pd} / \mathrm{C}$. A problem with this method is a strong dependence of the the same diacetate 39 .

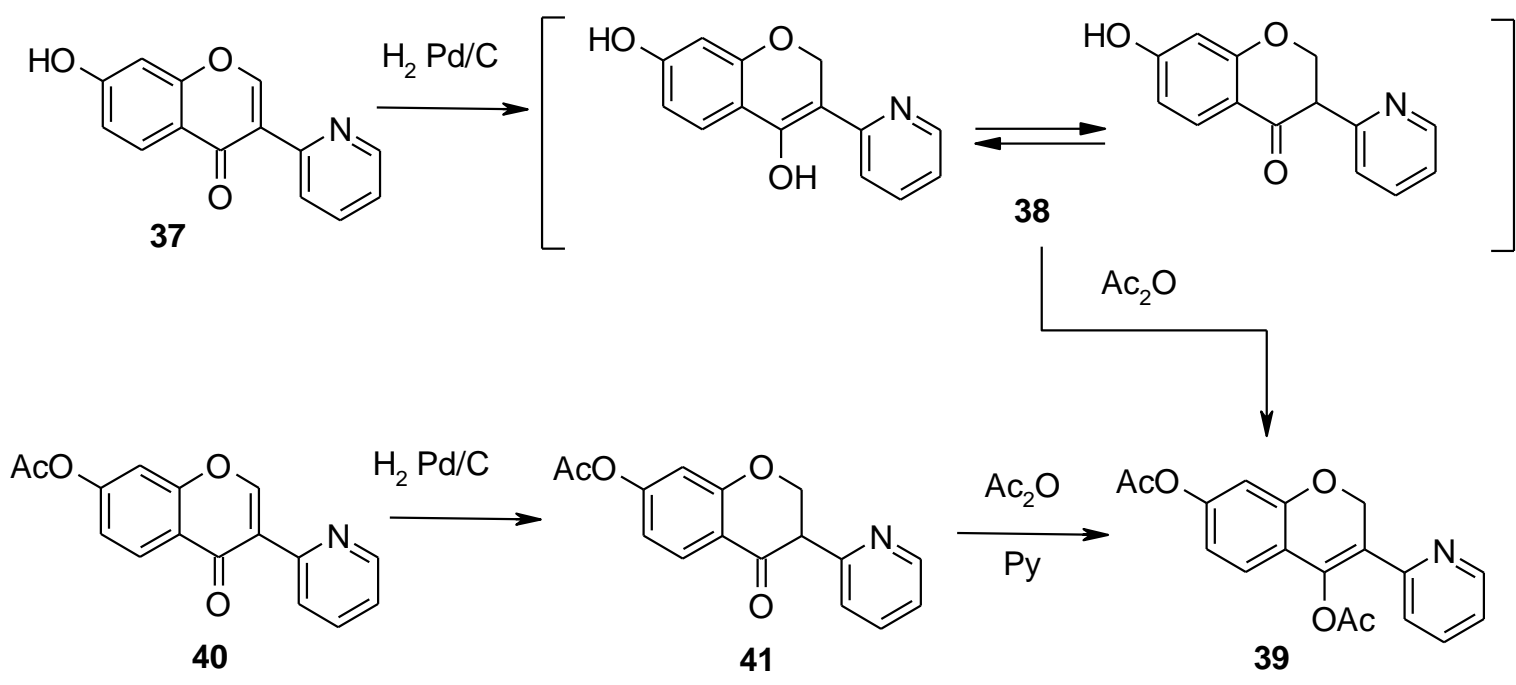

Scheme 14. Catalytic hydrogenation of 3-(2-pyridyl)chromone derivatives. 
<smiles>CCc1cc2c(=O)c(-c3ccc4ccccc4n3)coc2cc1OC</smiles><smiles>CCc1cc2c(cc1OC)OCC(c1ccc3ccccc3n1)=C2O</smiles>

Scheme 15. The synthesis of 6-ethyl-7-methoxy-3-(quinolin-2-yl)chroman-4-one.

The same strategy was applied for the conversion of 3-(2-quinolyl)-6-ethyl-7methoxychromone 42 into 3-(2-quinolyl)-6ethyl-7-methoxychroman-4-one 36 (Scheme 15). The latter was identical to the sample obtained by cyclization of 2-hydroxy-4methoxy- $\alpha$-(quinolin-2-yl)acetophenone with bisdimethylamino-methane.

A patent [27] reports on the hydrogenation of 6-epoxyethyl-3-(1H-tetrazol-5-yl)chromone to 6-hydroxyethyl-3-(1H-tetrazol-5yl)chromone using palladium black or $5 \% \mathrm{Pd}$ on activated carbon at r.t. or $100^{\circ} \mathrm{C}$. Only the epoxide ring was hydrogenolized, while the chromone double bond was not reduced.

Catalytic hydrogenation of 3piperidinochromone 43 in $0.2 \mathrm{~N}$ hydrochloric acid with $10 \% \mathrm{Pd}$ on carbon powder at r.t. resulted in 3-piperidinochromanol 44 [8] (Scheme 16).
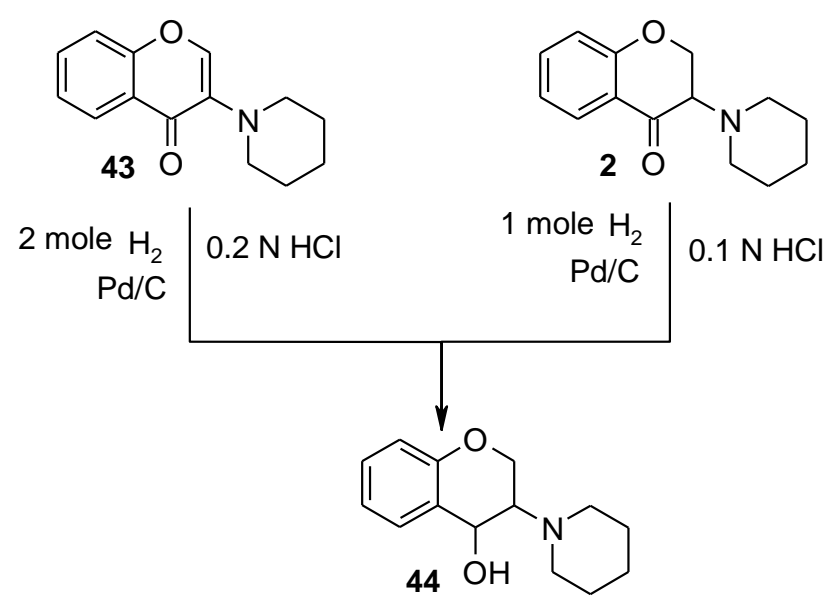

Scheme 16. The synthesis of 3-piperidinochromanol.

\subsection{Transfer hydrogenation}

In the chromone series, catalytic transfer hydrogenation (CTH) is an efficient alternative to catalytic hydrogenation. This type of hydrogenation does not involve hydrogen in gaseous form, but calls for other reducing agents.

3-Imidazolylchromone $\mathbf{4 5}$ was thus reduced to the corresponding chromanone 4 [28] in $53 \%$ yield by transfer hydrogenation in aqueous ethanol using the sodium hypophosphite-palladium catalyst reducing system, first described by Entwistle I.D. et al. [29] (Scheme 17). 
<smiles>O=c1c(-n2ccnc2)coc2ccccc12</smiles>

45

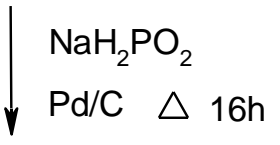<smiles>O=C1c2ccccc2OCC1n1ccnc1</smiles>

$4(53 \%)$

Scheme 17. The synthesis of 3-imidazolylchroman-4-one.

\subsection{Reduction with complex of hydrides}

According to information about the reduction of chromones with hydride complexes of aluminium and boron, the typical product of reduction are chromanols or chromans (after elimination of water from chromanols). Chroman-4-ones are generally not stable in the presence of complex hydrides and undergo further reduction. In confirmation of this statement, one may cite the synthetic pathway starting from 3-(1H-imidazol-1-yl)chroman-4one 15 leading to the corresponding 3-(1Himidazol-1-yl)chroman-4-ol (cis-trans mixture) 46 and 3-(1H-imidazol-1-yl)chromen 47 [10] (Scheme 18).<smiles>COc1ccc2c(c1)C(=O)C(n1ccnc1)CO2</smiles>

15

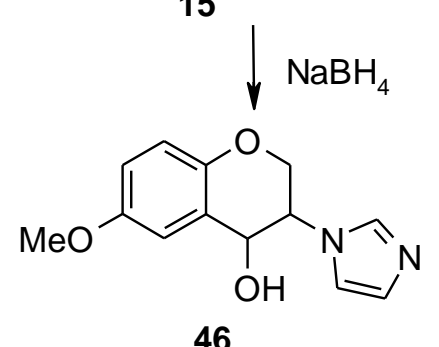<smiles>COc1ccc2c(c1)C=C(n1ccnc1)C([14CH3])O[C@H]2[14CH3]</smiles>

47

Scheme 18. Hydrogenation of 3-(1H-imidazol-1yl)chroman-4-one.

Cozzi et al. $[17,28]$ have studied the reduction of (un)substituted 3-(1H-imidazol-1-yl)- and 3(N-methylimidazol-2-yl)chromones. The 3-(1Himidazol-1-yl)chromones $\mathbf{4 8}$ were thus reduced with sodium borohydride to the corresponding chromanols 4 or 17 in high yields (Scheme 19).<smiles>[R]c1oc2ccccc2c(=O)c1-n1ccnc1</smiles>
$\mid \begin{aligned} & \mathrm{NaBH}_{4}, \mathrm{MeOH} \\ & 5-10^{\circ} \mathrm{C}\end{aligned}$<smiles>[R]C1Oc2ccccc2C(O)C1n1ccnc1</smiles>

4. $\mathrm{R}=\mathrm{H} \quad(96 \%)$

17. $\mathrm{R}=\mathrm{CO}_{2} \mathrm{Et} \quad(87 \%)$

Scheme 19. Hydrogenation of 3-(1H-imidazol-1yl)chromone. 
This reaction was attempted with imidazol-2-yl analogues 49 and the corresponding chromanols 50 were obtained in high yields as well (Scheme 20). They were obtained in the transtrans configuration as indicated by NMR spectral analysis.<smiles>[R]c1ccc2oc(C)c(-c3nccn3C)c(=O)c2c1</smiles>

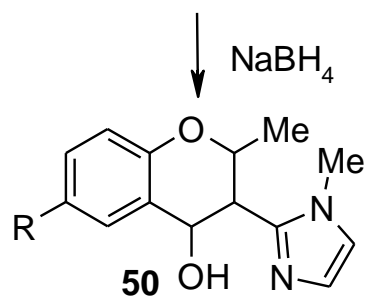

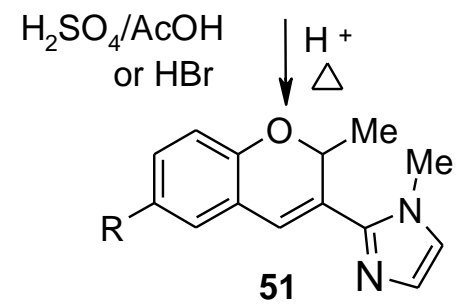

Scheme 20. Hydrogenation of 2-methyl-3-(1methylimidazol-2-yl)chroman-4-ones.

The chromanols $\mathbf{5 0}$ could be easily dehydrated to the chromenes $\mathbf{5 1}$ by heating in acetic acid in the presence of concentrated sulphuric acid or concentrated hydrobromic acid, in which case concomitant demethylation took place $(6-\mathrm{MeO}$ to $6-\mathrm{OH})$.

Khilya et al. have also studied the reduction of 3-(2-pyridyl)-7-methoxychromone 52 with sodium borohydride leading to 3-(2pyridyl)-7-methoxychroman-4-ol, which was isolated in practical quantitative yield as a mixture of cis- and trans- geometrical isomers 53 and 54 (Scheme 21).

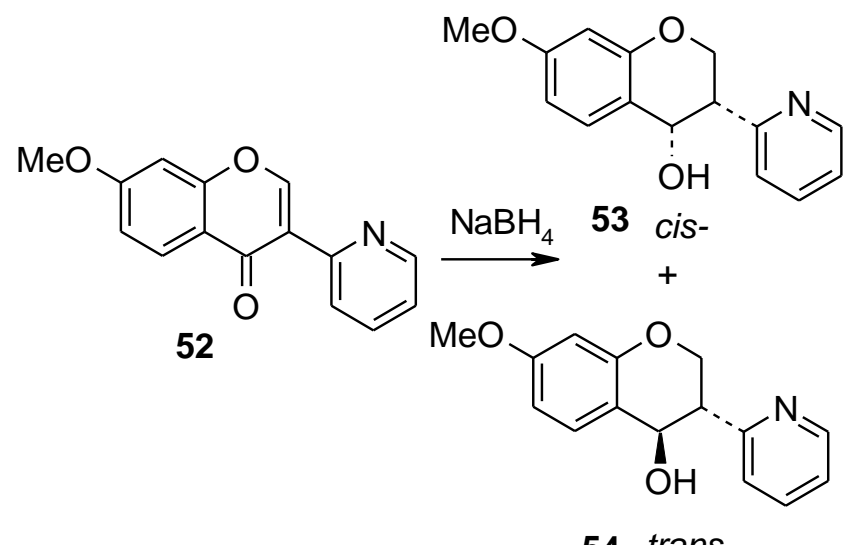

54 trans-

Scheme 21. Hydrogenation of 7-methoxy-3-(pyridin-2yl)chromen-4-one.

The mixture of geometrical isomers was resolved (in cis- $\mathbf{5 3}$ and trans- 54) by TLC on the silicagel plates. Confirmation of the stereochemical configuration and establishment of the tetrahydropyranes conformation were evidenced by NMR spectral data.

\subsection{Homogeneous hydrogenation}

Homogeneous catalytic hydrogenation is an important tool for the chemistry of chroman4-ones since it could proceed enantioselectivity.

Catalytic homogeneous hydrogenation of 7-methoxyisoflavone [30-32] and its pyridine analogues [31, 32] was first achieved in the presence of cationic iridium complexes.

The 7-methoxy-3-(pyridin-2yl)chromone $\mathbf{5 2}$ contains a very electrondeficient $\mathrm{C}=\mathrm{C}$-bond, since the pyridine ring is 
electron acceptor. Because of its unique electronic and steric properties, it was challenging to check the homogeneous hydrogenation outcome of this compound.

7-Methoxy-3-(pyridin-2-yl)chromone $\mathbf{5 2}$ was actually efficiently homogeneously hydrogenated under either electrophilic or nucleophilic conditions (under hydrogen pressure of $100 \mathrm{bar})$.

The conversion of $\mathbf{5 2}$ in presence of 1 mole-\% $[\operatorname{Ir}(\mathrm{COD})(i$-Pr-Phox $)] \mathrm{BARF}$ was $90 \%$ under nucleophilic conditions, and the use of 1,5 mole- $\%$ catalyst gave the 3-(pyridin-2yl)chroman-4-one $\mathbf{5 5}$ in $99 \%$ yield (after column chromatography) (Scheme 22) .

Hydrogenation of the chromone $\mathbf{5 2}$ under electrophilic conditions proved to be even more effective. It was thus observed that the use of iridium complexes such as $[\operatorname{Ir}(\mathrm{COD})((R)$ BINAP)]BARF, $\quad\left[\operatorname{Ir}(\mathrm{COD})\left(\mathrm{PPh}_{3}\right)_{2}\right] \mathrm{BARF}$, $\left[\operatorname{Ir}(\mathrm{COD})\left(\mathrm{PCy}_{3}\right)(\mathrm{Py})\right] \mathrm{PF}_{6}, \quad[\operatorname{Ir}(\mathrm{COD})((\mathrm{rac})-$ BINAP)]BARF or $[\operatorname{Ir}(\operatorname{cod})(i$-Pr-Phox $)]$ BARF (in 1 mole-\%) in such solvents as THF, $\mathrm{CH}_{2} \mathrm{Cl}_{2}$, $\mathrm{PhMe}$ or $\mathrm{MeOH}$ resulted in $100 \%$ convertion of the chromone 52. 7-Methoxy-3-(pyridin-2yl)chroman-4-one 55 was isolated in 94-96\% yield after column chromatography (Scheme 23).<smiles>COc1ccc2c(=O)c(-c3ccccn3)coc2c1</smiles>

52 $\downarrow \begin{aligned} & \mathrm{H}_{2} \\ & {[\operatorname{Ir}(\mathrm{COD})(4 \mathrm{~S})-i \text {-Pr-Phox]BARF }} \\ & \text { toluene, DIPEA }\end{aligned}$<smiles>COc1ccc2c(c1)OCC(c1ccccn1)C2=O</smiles>

55

Scheme 22. Homogeneous hydrogenation of 2-methoxy3-(pyridin-2-yl)chromen-4-one under nucleophilic conditions.<smiles>COc1ccc2c(=O)c(-c3ccccn3)coc2c1</smiles>

52

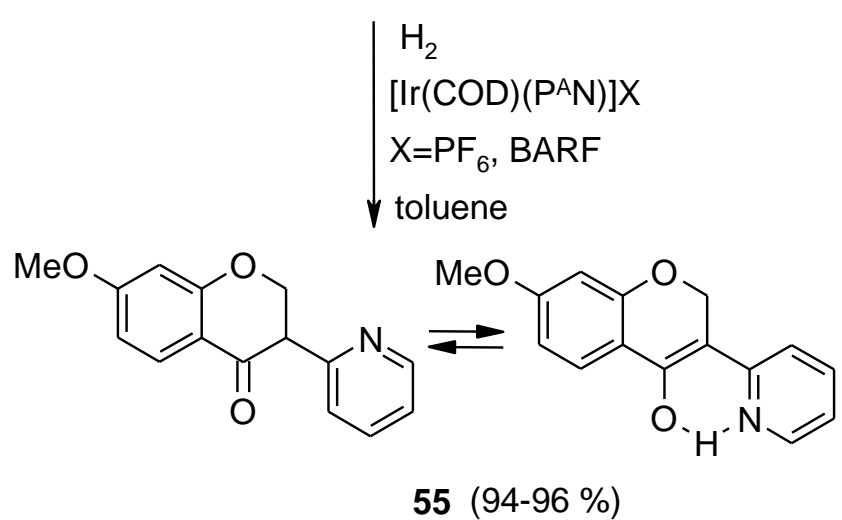

Scheme 23. Homogeneous hydrogenation of 7-methoxy3-(pyridin-2-yl)chromen-4-one under electrophilic conditions

Complexes of rutenium left 7-methoxy-3(pyridin-2-yl)chromone $\mathbf{5 2}$ intact and complexes of rhodium were not effective.

The enantiomers of the 3-(pyridin-2yl)chroman-4-one $\mathbf{5 5}$ were not totally resolved (to baseline) on analytical chiral HPLC. The reason of this failure for resolution is an 
enolization process occurring even in unpolar solvents. The use of the chiral lantanoid shift reagent $\mathrm{Eu}(\mathrm{tfc})_{3}$ resulted in a splitting of ${ }^{1} \mathrm{H}$ NMR resonance frequencies of the two enantiomers. Nevertheless, NMR analysis under such resolving conditions of 3-(pyridin-2yl)chroman-4-one 55, obtained in presence of chiral nonracemic catalysts, showed that the product was generated in racemic form. This is not surprising, as the chromanone $\mathbf{5 5}$ is prone to undergo enolization, which deletes the chiral center. The enolization process is spontaneous, without requiring any additive (e.g. bases or acids) and occurs readily at r.t. Enolization of the chromanone $\mathbf{5 5}$ is indeed favored by the formation of a new hydrogen bond (Scheme 23). Enolization takes place even in low polar solvents $\left(\mathrm{C}_{6} \mathrm{D}_{6}, \mathrm{CDCl}_{3}\right.$ or in THF-D 8$)$ and in solid state and makes the enantiomerically pure chromanone 55 unavailable

\section{Other methods for the synthesis of 3- hetarylchroman-4-ones}

Litkei et al. [33] have performed an easy and convenient method for the synthesis of the hitherto unknown trans-2-phenyl-3tetrazolylchroman-4-one 56 (Scheme 24). Trans-3-aminoflavanone $\mathbf{5 7}$ is known to be stable only in the form of its hydrochloride reacts with sodium azide and ethyl ortoformiate in hot acetic acid to afford trans-2-phenyl-3tetrazolylchroman-4-one $\mathbf{5 6}$ in $59 \%$ yield. The starting 3-aminoflavanone 57 [34] was readily obtained by application of the Neber reaction to 4-oximinoflavan tosylate.<smiles>O=C1c2ccccc2O[C@@H](c2ccccc2)C1N=CCl</smiles>

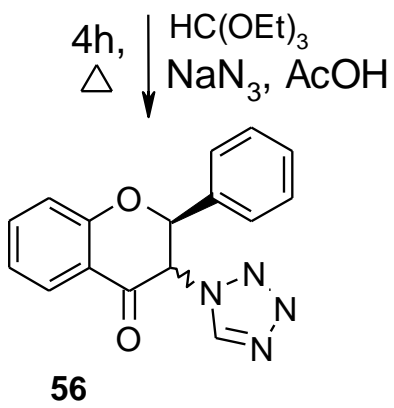

Scheme 24. The synthesis of trans-2-phenyl-3tetrazolylchroman-4-one.

\section{Biological activity of 3-hetarylchroman-4- ones}

3-Hetarylchroman-4-ones exhibit an interesting spectrum of biological activity.

Just so, 3-(2-pyridinyl)chroman-4-one $\mathrm{N}$ - oxides possess antiulcer activity in rats at 10$100 \mathrm{mg} / \mathrm{kg}$ [16].

A series of 3-(1-imidazolyl)chroman-4ones were tested and a family of hypolipidemic agents with unusual positive features were identified [11]. In rats submitted to an atherogenic diet, 3-(1-imidazolyl)chroman-4ones, bearing appropriate lipophilic substituents on the phenyl ring, were found to induce a lowering of the total cholesterol, markedly lowering LDL and raising HDL. This activity was accompanied by an increase in liver weight, 
which was correlated to some degree, with microsomal induction but not with peroxisome proliferation. On the other hand, hypolipidemic and peroxisome proliferators agents (e.g. clofibrate and related compounds) lowered total serum cholesterol but failed, in normolipemic rats, to raise the HDL/LDL ratio to the same extent as described for 3-(1imidazolyl)chroman-4-ones. Derivatives of 3(1-imidazolyl)chroman-4-one were patented for a use in prevention and therapy of atherosclerosis, owing to inhibition of blood platelet aggregation, increase total serum HDL cholesterol, increase of the ratio between $\alpha$ lipoprotein and $\beta$-lipoprotein total cholesterol, and/or reducing total serum cholesterol or serum triglycerides [35].

A series of 3-azolylchroman-4-one derivatives was aimed at investigating anticonvulsant activity [20], owing to the fact that these compounds are conformationally constrained analogs of (arylalkyl)azole anticonvulsants (loreclezole, nafimidone, denzimole). The anticonvulsant activities were evaluated by determining seizure latency and protective effect against pentylenetetrazole (PTZ)-induced lethal convulsion in mice at a dose of $5 \mathrm{mg} / \mathrm{kg}$, where sodium valproate at a dose of $150 \mathrm{mg} / \mathrm{kg}$ was taken as a reference treatment. Among the examinated compounds, 7-chloro-3-(1H-imidazol-1-yl)chroman-4-one and 3-(1H-1,2,4-triazol-1-yl)chroman-4-one exhibited significant activity in delayin seizures as well as effective protection against PTZinduced seizures and deaths. No effective compound was identified in the triazol-4-yl series. It has often been stated that seizures induced by PTZ can be suppressed by drugs that reduce T-type $\mathrm{Ca}^{2+}$ currents, such as ethosuximide, and drugs that enhance $\mathrm{GABA}_{\mathrm{A}}$ receptor-mediated inhibitory neurotransmission, such as benzodiazepines or phenobarbital. So it is possible that the azolylchroman-4-ones exert their anticonvulsant action by modulation of $\mathrm{Ca}^{2+}$ currents or $\mathrm{GABA}_{\mathrm{A}}$ receptor. As anticonvulsant agents that inhibit seizures induced by PTZ 3azolylchroman-4-ones can be considered effective in the treatment of generalized myoclonic and absence seizures.

In addition, 3-azolylchroman-4-ones are intermediates in the design of some antifungal agents [20-22, 36].

\section{Conclusions}

In conclusion, a variety of approaches to the synthesis of 3-azahetarylchroman-4-ones has been presented and discussed in view of their advantages and disadvantages as well as trends for their future development. This review highlights that the researches in the field of 3azahetarylchroman-4-ones is both of theoretical and practical significance. Gathered in the same molecule, N-containing heterocycles and chromanone cores represent a useful source for 
the discovery of novel physiologically active compounds.

\section{References}

[1] N. V. Gorbulenko, V. P. Khilya, Ukr. Khim. Zh., 1994, 60, 1, 79.

[2] M. S. Frasinyuk, V. P. Khilya, Chem. Heterocycl. Comp., 1999, 35, 1, 3.

[3] V. P. Khilya, V. V. Ishchenko, Selected Methods for Synthesis and Modification of Heterocycles, ed. by Prof. V. G. Kartsev., Interbioscreen monographs series, IBS Press., v.2, p.140.

[4] Ch. K. Ghosh, Heterocycles, 2004, 63, $12,2875$.

[5] V. Semeniuchenko, U. Groth, V. Khilya, Curr. Org. Synth., 2010, 7, 279.

[6] I. M. Lockhart, E. M. Tanner, J. Chem. Soc., 1965, 3610.

[7] J. Colonge, A. Guyot, Bull. Soc. Chim. France. 1958, 329.

[8] P. W. Feit, Acta Chem. Scand. 1964, 18 $10,2401$.

[9] C. W. Winter, C. S. Hamilton, J. Am Chem. Soc., 1952, 74, 3999.

[10] P. Cozzi, N. Mongeli, A. Pillan, J. Heterocyl. Chem. 1984, 21, 311.

[11] P.Cozzi, U. Branzoli, P. P. Lovizolo, G. Orsini, G. Carganico, A. Pillan, A. Chiari, J. Med. Chem., 1986, 29, 404.

[12] S. Emami, A. Shafiee, Heterocycles 2001, 55, 11, 2059..

[13] P. Strehlke, G. A. Hoyer, E. Schroder, Arch. Pharm., 1975, 308, 94.

[14] H. K. Lai, R. A. Davis, A. R. Blem, U.S. US 5.006.153 (1991). (CA, 1991, 115 71617k).

[15] D. T. Conner, P. A. Young, M. von Strandtmann, J. Heterocyclic Chem., 1977, 14, 143.
[16] D. T. Connor, P. A. Young, M. von Strandtmann, (Warner-Lambert Co.) US 4.013.673 (1976), (CA 1976, 87, 23047f).

[17] P. Cozzi, A. Pilan, J. Heterocycl. Chem., 1986, 23, 6, 1693.

[18] H. Baji, M. Flammang, T. Kimny, F. Gasquez, P. L. Compaguou, A. Delcourt, Eur. J. Med. Chem., 1995, 30, 617.

[19] B. A. Astleford, G. L .Goo, J. G. Keay, E. F. V. Scriven, J. Org. Chem., 1989, 54, 731.

[20] S. Emami, A. Kebriaeezadeh, M. J. Zamani, A. Shafiee, Bioorg. \& Med. Chem. Lett., 2006, $16,7,1803$.

[21] S. Emami, M. Falahati, A. Banifatemi, M. Amanlou, A. Shafiee, Bioorg. \& Med. Chem., 2004, 12,3971 .

[22] S. Emami, M. Falahati, A. Banifatemi, A. Shafiee, Bioorg. \& Med. Chem., 2004, 12, 5881.

[23] I. Jijima, M. Miyazaki, T. Tanaba, Japan Kokai 7626877( 1976). ( CA 1976, 85, 159884t ).

[24] I. Jijima, N. Taga, M. Miyazaki, T. Tanaka, J, Usawa, J. Chem. Soc., Perkin Trans. 1, 1979, 12, 3190. ( CA 92, 128664m ).

[25] V. Scabo, E. Antal, Tetrahedr. Lett., 1973, 19, 1659.

[26] V. Scabo, E. Antal, Acta Chim. Acad. Sci. Hung., 1976, 90, 381.

[27] A. Nohara, T. Jshiguro, K. Ukawa, JP 54059279 ( 1979). (CA 1979, 91, 175358).

[28] P. Cozzi, A. Pillan, J. Heterocycl. Chem., 1985, 22, 441.

[29] I. D. Entwistle, A. E. Jackson, R. A .W. Johnstone, R. D. Telford, J. Chem. Soc., Perkin Trans. 1., 1977, 443.

[30] V. Semeniuchenko, V. Khilya, U. Groth, Synlett, 2009, 2, 271.

[31] V. Semeniuchenko, Dissertation, Konstanz, Germany, Avail. Metadata on Internet Documents, Order № 393201, 2009: CA 2009, v. 151: 
172916; http: //nbn-resolving.de/urn:nbn:d:bsz:352-opus80951.

[32] V. Semeniuchenko, T. E. Exner, V. Khilya, U. Groth, Appl. Organometal. Chem. 2011, 25 804.

[33] Gy. Litkei, T.Patonay, E. Patonay-Peli, V. Khilya, Pharmazie, 1989 , 44, 11, 791.

[34] C. O’Brien, E.M. Philbin, S. Ushioda, T.S. Wheeler, Tetrahedron, 1963, 19373.

[35] Farmitalia Carlo Erba S.p.A., US 4342775 A 1 ( 1982).

[36] S. Emami, M. Falahati, A. Banifatemi, K. Moshiri, A. Shafiee, Arch. Pharm. Pharm. Med. Chem., 2002, 7, 318. 